\title{
Misterium życia konsekrowanego - wyzwania i nadzieje naszych czasów
}

\section{THE MYSTERY OF CONSECRATED LIFE - THE CHALLENGES AND HOPES OF OUR TIMES}

A parable, applied to the structure of the Dogmatic Constitution on the Church Lumen gentium and the essence of the personal consecration, is the key to interpret the mystery of the Church and personal consecration through the profession of the evangelical counsels.

The consecration has been presented as a "proper experience": of the Son of God (Jn 10:36 - hégiasen kai apesteilen); of the Church (all are consecrated through the baptism and confirmation; some through a new consecration); of a person called to this state.

The essence of personal consecration has been defined in three elements: vocatio (verified by the Church); sacrificatio (the response for calling, in the form of giving one's life to ministry); sanctificatio (a life transformed to appeal in a meaningful way - cf. VC 20).

The ideal fulfilled in Christ and in the Church (various historical and new forms) is a challenge for contemporary vocations. The challenge lies in the deformations, crises; the hopes are related to God's faithfulness, the radicalism of the young (evangelical radicalism) and solid formation.

Key words: consecration, mystery, vocation (vocatio), devotion (sacrificatio - devoting oneself), sanctification (sanctificatio), formation, Christ-forming.

Cytat, od którego rozpocznie się niniejsza refleksja, pozwoli zrozumieć, dlaczego do oglądu misterium przydatny jest klucz paraboli: 
Teologia duchowości

Społeczeństwo dobrobytu szuka coraz bardziej laickich spowiedników. Ich naukowe poznanie ma doprowadzić do ładu rozbite i puste życie ludzkie. Oni mają odkryć co to jest miłość, słowo i w ogóle wszystkie podstawowe wartości. Ale, czy naprawdę mogą pomóc ci lekarze? Wprawdzie mogą oni określić, jak funkcjonują poszczególne siły duszy ludzkiej, lecz nie mogą powiedzieć, po co działają. Rozpad duszy ludzkiej polega tymczasem właśnie na tym, że jej siły poruszają się w pustce [...] Dusza żyje w otwartym układzie krążenia, powiedzmy ściślej: $w$ otwartej paraboli, i nie można jej uleczyć pomijając punkt odniesienia, który leży poza nią samą ${ }^{1}$.

Refleksja dotycząca „misterium życia konsekrowanego” odsyła już przez sam tytuł do trzech pojęć, które niełatwo jest pochwycić w słowo, i stąd trudnych do wyrażenia od strony treści.

Truizmem byłoby powtarzać, że misterium nie podlega definiowaniu, jest raczej przedmiotem oglądu kontemplacyjnego, który można przełożyć na teologiczny opis. Poza tym, przedmiotem naszej refleksji nie są instytuty życia konsekrowanego, ale życie (sic!), a więc tajemnica, której nauki szczegółowe nie mogą uchwycić integralnie (badają ją tylko aspektowo: medycznie, psychicznie, biologicznie itd.). Wreszcie, samo pojęcie 'konsekracja' zastosowane do życia vel osoby niejednoznaczne w punkcie wyjścia - domaga się uwzględnienia wielu płaszczyzn, by odsłonić jego istotę i sens praktyczny.

W prezentowanej refleksji misterium życia konsekrowanego odsłoni się w kilku wymiarach powiązanych wzajemnie i tworzących integralną całość:

- jako doświadczenie własne Jezusa Chrystusa;

- doświadczenie własne Kościoła;

- personalne doświadczenie tego, który do konsekracji życia został powołany.

Arcybiskup Edward Ozorowski postawił słuszny zarzut, że sakramentologia, eklezjologia i trynitologia zostały w teologii akademickiej ,zobiektywizowane, żeby nie powiedzieć urzeczowione [...] sakramenty i Kościół to przede wszystkim sprawa życia człowieka: pojedynczego i we wspólnocie. Chodzi tu o to, co nazywamy życiem wewnętrznym nadprzyrodzonym, które wynosi istnienie człowieka na

1 J.Ratzinger,Dogmaund Verkündigung, München 1973, s. 444, cyt.za: J.Ratzinger, Stużyć Prawdzie, Myśli na każdy dzień, tł. ks. A. Warkotsch, Poznań - Warszawa - Lublin 1986, s. 78. Opracowanie powstało za aprobatą ówczesnego Prefekta Kongregacji Nauki Wiary, uzyskanego przez s. Irenę Grassl w maju 1977 roku. Za przyzwoleniem Autora, zestawiła ona fragmenty wyjęte z różnych jego pism, tworząc antologię tekstów do medytacji na każdy dzień roku. 
poziom właściwy Bogu"2. Dla uniknięcia wskazanego niebezpieczeństwa, zagadnienie zostanie przedstawione językiem relacji interpersonalnych odnoszonym do wymiaru wiary, która - jak podkreślił Jan Paweł II w encyklice Fides et ratio jako jedyna, ,tylko wiara, pozwala wniknąc do wnętrza tajemnicy [misterium] i pomaga ją poprawnie zrozumieć" (nr 13).

Papież Franciszek zalecił, by w Roku Życia Konsekrowanego uwzględnić w namyśle przeszłość, teraźniejszość i przyszłośćc ${ }^{3}$. Wyzwania z tej przestrzeni można sprowadzić do kwestii przenikania się wzajemnego powyższych wymiarów, określonej drożności w tym względzie. Nadzieje zaś do skuteczności łaski wobec tego, co od strony człowieka niedojrzałe i zdeformowane.

\section{Konsekracja życia - doświadczenie własne Syna Bożego}

Pierwszą osobą konsekrowaną, wpisaną w przedwieczne zamysły Boże jest Jednorodzony Syn, którego „Ojciec poświęcił [konsekrował] i posłał na świat" (J 10,36: grec. hēgiasen kai apesteilen - uświęcił i wysłał).

Znaczy to, że kwestia „,poświęcenia” zrodziła się w życiu wewnętrznym Boga. Fakt, iż „Ojciec poświęcił” Syna - to największe revelatio w wierze Kościoła, gdyż nie jest ono zaledwie dobrą „wieścią”, ale rewelacyjnym faktem, skonkretyzowanym personalnie darem. „Ten, który jest Synem Bożym na łonie Ojca i który jest Słowem Ojca, został wybrany, aby objawić ludziom, że są na Jego wzór przeznaczeni, aby byli synami przybranymi"".

Jego poświęcenie jawi się jako „pierwsze” wobec każdego innego poświęcenia się osoby. W tym misterium odsłania się głęboki wymiar miłosiernej Miłości Boga, o której św. Jan Paweł II napisał: „Miłość Ojca objawiła się w Synu jako miłość odkupieńcza. Ta właśnie miłość stanowi właściwą cenę Odkupienia człowieka i świata"(adh. Redemptionis donum, $\mathrm{nr}$ 3). Kryje się w niej zarówno poświęcenie Ojca, który własnego „Syna nie oszczędził”(por. Rz 8,31), by człowiek w doczesności mógł doświadczyć intymnego spowicia Bożą miłością, które usuwa grzech i napełnia świętością. Łaskawy zamysł Ojca nie

2 E. Ozorowski, Bóg - Życie, Miłość, Komunia, [w:] A. Czaja, P. Jaskóła (red.), Wokót Tajemnicy Trójcy Świętej, Opole 2000, s. 15.

3 Por. Franciszek, List do wszystkich osób konsekrowanych na Rok Życia Konsekrowanego: Świadkowie radości, (21 XI 2014), nr 1-3, por. Vita consecrata, nr 110.

4 S. Moysa, Rola Kościoła w przekazywaniu Objawienia, [w:] H. Bogacki, S. Moysa (red.), Kościót w świetle Soboru, Poznań 1968, s. 21. 
Teologia duchowości

obejmuje nawracania ludzkości za pomocą jakiejś „instrukcji życia”, którą miałaby być zbawienną. Ojciec postawił pośród ludzi umiłowanego Syna, by naocznie mogli przekonać się, że w doczesności można wytrwać w jedności z Nim i wypełnić Jego wolę.

Jezus Chrystus ten odwieczny zamysł Ojca wpisał w misterium Kościoła, o którym, tak jak o Ojcu mówi z dodaniem zaimka „mój” (np. $\mathrm{J} 5,31 ; \mathrm{J} 6,39 ; \mathrm{J} 8,18$ oraz Mt 16,18). Do misterium Ecclesiae zastosujemy również klucz paraboli.

Okazuje się on przydatny do odczytania struktury konstytucji dogmatycznej o Kościele Lumen gentium. Lektura w kluczu parabolicznym pozwala łatwiej uchwycić soborowy zamysł odnowy życia chrześcijańskiego i zakonnego (ad fontes; accomodata renovatio). Tekst, którego strukturę ułoży się liniowo, dla osób konsekrowanych może być deprymujący, gdyż rozdział im poświęcony sytuuje się dopiero na szóstym miejscu ${ }^{5}$, po laikacie, którego teologię omówiono w czwartym rozdziale.

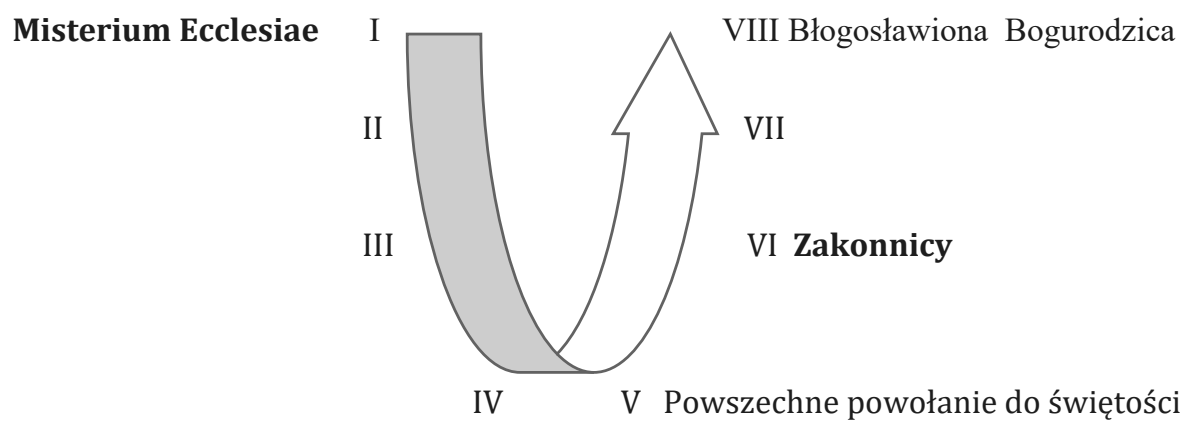

Uczestnik Soboru i współtwórca tej wizji Kościoła, Jan Paweł II później, w jednej z katechez papieskich (5 IV 1995) - podkreślił: „Ojciec, który swym sercem obejmuje wszystkich, poprzez Syna i Ducha ustanawia kult powszechny. Jak powiedziałem w encyklice Redemptoris missio, Kościół wyłania się z serca Ojca i jest katolicki, ponieważ Ojciec otwiera swoje ojcostwo wobec całej ludzkości (por. n.12)"․ Misją Kościoła jest więc prowadzenie całej ludzkości, człowieka każdej kultury i religii, do Serca Ojca.

$5 \quad$ Zob. T. Paszkowska, Misterium konsekracji osób $w$ perspektywie duchowości Soboru Watykańskiego II, Lublin 2005, s. 33-35. 


\section{Konsekracja osób jako doświadczenie Kościoła}

Kościół jest tą wybraną przez Boga „przestrzenią” (certus locus), w której dokonuje się odsłanianie misteriów Bożych wobec kolejnych pokoleń. Kościól jest epifania misterium i sam ma naturę misterium.

„Kościoła nie wyczerpują kategorie apersonalne: rzeczy, idee, struktury, stany..." Misterium Ecclesiae wyłania się z misterium Trinitatis, dzięki czemu „życie Przenajświętszej Trójcy staje się udziałem ludzi” (Lumen gentium, nr 1). Już Orygenes utworzył formułę: „Kościół pełen Teologia duchowości Trójcy" ", którą spożytkowano później w instrukcji Kongregacji poświęconej formacji osób zakonnych. W tym znaczeniu można powiedzieć, że Kościół - na sposób sakramentalny - jest „obecnością Misterium” (la présence du Mystère $)^{9}$ albo „konkretyzacją Misterium” (la concrétisation du mystère $)^{10}$.

Termin misterium w eklezjalnym kontekście nabiera wyraźnie znaczenia pozytywnego, wskazuje na odsłanianie się, objawianie tego, co było dotąd niepojęte lub zasłonięte (re-velatio).

Kościół wprowadza ludzi w Misterium Boga - według trafnego określenia kard. de Lubaca - ,poprzez podwójne drzwi zawsze otwarte Doktryny i Liturgii" "11. Nie jest możliwe zrozumieć Kościół inaczej niż „poprzez dochodzenie do jego źródeł i próby zrozumienia go w epokach jego eksplodującej żywotności? Jak odnaleźć znaczenie wielu doktryn i wielu instytucji, jeśli nie poprzez wysiłek dotarcia do tej myśli kreującej, której stały się one konkretyzacją? [...] potrzeba było czterdziestu lat, by wejść do Ziemi Obiecanej. Czasami potrzeba wiele

$7 \quad$ R. Skrzypczak, Kościót jako Niewiasta w relacji do Chrystusa swego Oblubieńca, Warszawa 2001, s. 70.

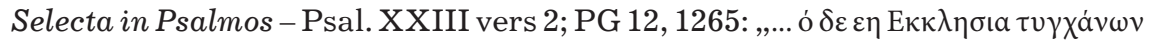

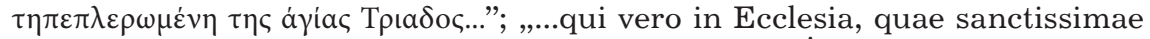
Trinitatis plena est...”. Zob. Kongregacja Instytutów Życia Konsekrowanego i Stowarzyszeń Życia Apostolskiego, Wskazania dotyczące formacji w instytutach zakonnych: Potissimum Institutioni (2 II 1990), nr 23. Tekst grecki i łaciński przytaczam z 12 tomu Patrologiae cursus completus. Series Graeca., wyd. J. P. Migne.

$9 \quad$ Określenie M.-J. Le Guillou, G. Lafont, L’Eglise en marche, Paris 1964, s. 211, cyt. za : G. R. Alberti, Teología del misterio el pensamiento teológico de Marie-Joseph Le Guillou O.P., Mursia 2000, s. 121. Alberti - pracownik Uniwersytetu Laterańskiego - w rozprawie doktorskiej podjął refleksję nad kategorią misterium charakteryzującą myśl teologiczną francuskiego dominikanina M.-J. Le Guillou (1920-1990). Zob. zwłaszcza rozdz. III rozprawy, s. 73-138.

10 Takie określenie przyjął L. Cerfaux, zob. La sotériologie paulinienne, „Divinitas"5(1961) s. 112, cyt. za: Alberti, Teología del misterio, s. 121.

H. de Lubac, Medytacje o Kościele, Kraków 1997, s. 227. 
Teologia duchowości

suchej pracy archeologicznej, by wytrysły od nowa fontanny wody żywej” ${ }^{12}$. Dla wierzących to Chrystus stanowi zasadniczy „kwantyfikator tej Boskiej Ekonomii: Ekonomii Przyjścia, Przejścia i Wejścia...”13, który wprost wskazuje na inność Bożych dróg w porównaniu z drogami ludzkimi. Światło tej ekonomii prześwietla strukturę ludzkiego bytowania ujawniając, że „człowiek - to byt ku chwale"14.

Jeżeli Syn Boży codziennie przychodzi do swego Kościoła przede wszystkim drogą (gr. methodos) konsekracji. Jeśli w Ciele i Krwi jednoczy się z tymi, których wybrał i przywołał, by ich prowadzić do Ojca, to już sam akt włączenia człowieka do Kościoła musi mieć charakter konsekracji. Poprzez chrzest „człowiek zmienia niejako swoją naturę stając się «jednym» z Chrystusem (Rz 6,5)"15. Dzieje się to zwykle w okresie niemowlęcym, co tym wyraźniej ujawnia się moc łaski:

człowiek może zmienić mentalność, choć trzeba do tego długotrwałych zabiegów; może zmienić wolę, przyjmując nowe motywacje i uznając nowe cel; człowiek może zmienić postępowanie ku niemałemu zdumieniu własnemu i bliźnich; ale nie może człowiek zmienić swojej istoty. Tylko Bóg Stwórca może to zrobić. I Bóg to robi, dając nowe tchnienie życiowe ${ }^{16}$.

W przyjętej logice, Kościół jawi się jako przestrzeń, w której istnieje wiele konsekracji - wszystkie w ścisłym powiązaniu z konsekracją eucharystyczną - a osoby włączone do Kościoła są wielorako konsekrowane. Ta wielorakość najpierw odnosi się do sakramentów: „wszyscy w Kościele są konsekrowani przez chrzest i bierzmowanie" "17, a posługa święceń i życie konsekrowane (w sensie ścisłym) wiążą się z dodatkową formą konsekracji, która przygotowuje także do specjalnej misji w Kościele ${ }^{18}$.

Przy tym, należy zauważyć, że „wizja Kościoła złożonego wyłącznie z szafarzy i z wiernych świeckich nie odpowiada zamiarom jego

12 H. de Lubac, cyt. za: E. dal Covolo, Studium Ojców Kościoła dla kultury zjednoczonej Europy, „Seminare”20(2004), s. 241.

13 K. Wojtyła, Znak sprzeciwu, Rekolekcje w Watykanie od 5 do 12 marca 1976, Kraków 1995, s. 69.

$14 \quad$ Ibidem, s. 71.

15 E. Samsel, „Święci” a wspólnota chrześcijan wedtug świętego Pawła Apostoła, [w:] B. Bejze (red.), W nurcie zagadnień posoborowych, t.6, Błogostawiony Maksymilian wśród nas, Warszawa 1972, s. 358.

16 J.Dąbrowski, Nowośćżycia wliturgii chrztuświętego, [w:]A. J. Nowak, W. Słomka (red.), Chrzest - nowość życia, Homo meditans, t. 10, Lublin 1992, s. 58.

17 Vita consecrata, nr 31.

18 Por. ibidem. 
Boskiego Założyciela, jakie możemy odczytać z Ewangelii i z innych pism Nowego Testamentu" (VC 29).

Życie zakonne w Kościele nie jest zwykłą radykalizacją chrztu, gdyż chrzest „nie czyni nikogo świeckim ani zakonnikiem”, można powiedzieć, że „otwiera wszystkie drogi, lecz sam w sobie nie określa jeszcze żadnego konkretnego wyboru [...] nie tworzy drogi laikatu, lecz drogę chrześcijaństwa" ${ }^{19}$. To raczej bierzmowanie specyfikuje to powołanie, które chrześcijanin dojrzewający - w wierze i osobowościowo - odkryTeologia wa jako właściwe dla siebie, by podjąć zadania w Kościele i świecie.

Ogólnie można przyjąć, że w Kościele konsekracja nie uniformizuje i nie unifikuje wybranych, lecz specyfikuje charyzmatycznie do zadań, które muszą być podjęte w ramach misji zleconej przez Pana Kościołowi.

Do eklezjalnych form konsekracji życia adhortacja Vita consecrata zalicza:

- monastycyzm na Wschodzie i Zachodzie (VC 6 - mnisi są niosącymi Krzyż i niosącymi Ducha - gr. staurophóroi; pneumatophóroi);

- stan dziewic Bogu poświęconych, konsekrowanych wdów (wdowców); pustelników (pustelnic) wywodzących się ze świeckich, zakonów i zgromadzeń (VC 7);

- instytuty monastyczne i zakonne oddane całkowicie kontemplacji (VC 8);

- liczne zgromadzenia zakonne oddane dziełom apostolskim(VC 9);

- nowe formy życia konsekrowanego, jak instytuty świeckie czy kleryckie instytuty niezakonne (VC 10);

- stowarzyszenia życia apostolskiego (VC 11).

W jednej osobie powołanej mogą zbiegać się różne formy konsekracji, przyjęte w różnej kolejności (np. chrzcielna, z bierzmowania, z profesji rad ewangelicznych, z sakramentu święceń).

Nie konsekracja różni osoby powołane i Bogu poświęcone, ale forma ich profesji (ślubów, przyrzeczeń, zobowiązań) złożonych Bogu i wypełnianych dla dobra całego Kościoła (w ramach określonego charyzmatu, przez Kościół rozeznanego i potwierdzonego).

Zwykle profesja odnosi się do rad ewangelicznych - dopiero od drugiego tysiąclecia istnienia Kościoła - jednak w przypadku indywidualnych form życia konsekrowanego nie chodzi o triadę: czystość, ubóstwo, posłuszeństwo, ale np. dziewicze czy wdowie oddanie życia przez pośrednictwo biskupa (na rzecz Kościoła lokalnego).

Można spojrzeć na całą rzeczywistość Kościoła jako na wspólnotę osób (wielorako) konsekrowanych czy - inaczej ujmując - jako na

19 P. Liszka, Charyzmatyczna moc życia zakonnego, Wrocław 1996, s. 80. 
Teologia duchowości

przestrzeń dokonywania się wielorakich konsekracji wzajemnie dopełniających się i sobie przyporządkowanych.

Sprawę wzajemnych powiązań pomiędzy różnymi stanami życia chrześcijańskiego na obecnym etapie dziejów Kościoła, objaśnia adhortacja Vita consecrata w nr 31-32 ${ }^{20}$.

$20 \quad$ VC 31: Zgodnie z zamysłem Pana Jezusa życie Kościoła urzeczywistnia się w różnych formach. Istnieją między nimi wzajemne powiązania, którym warto poświęcić uwagę. Dzięki odrodzeniu w Chrystusie wszyscy wierni mają udział we wspólnej godności; wszyscy są powołani do świętości; wszyscy współdziałają w budowaniu jedynego Ciała Chrystusa, każdy zgodnie z własnym powołaniem i darem otrzymanym od Ducha Świętego (por. Rz 12,3-8). Równa godność wszystkich członków Kościoła jest dziełem Ducha, opiera się na chrzcie i bierzmowaniu, a umacnia się dzięki Eucharystii. Jednakże dziełem Ducha jest także wielość form. To On buduje Kościół jako organiczną komunię, obejmującą wielorakie powołania, charyzmaty i posługi.

Powołania do życia świeckiego, do posługi święceń i do życia konsekrowanego mają charakter paradygmatyczny, jako że w taki czy inny sposób wywodzą się z nich lub do nich się odwołują wszystkie powołania szczególne, przyjęte oddzielnie lub łącznie, zależnie od bogactwa daru Bożego. Ponadto służą one sobie nawzajem, wspomagając wzrost Ciała Chrystusa w historii i jego misję w świecie. Wszyscy w Kościele są konsekrowani przez chrzest i bierzmowanie, ale posługa święceń i życie konsekrowane zakładają istnienie odrębnego powołania oraz szczególnej formy konsekracji, która przygotowuje do specjalnej misji.

Dla misji wiernych świeckich, którzy mają ,,szukać Królestwa Bożego, zajmując się sprawami świeckimi i kierując nimi po myśli Bożej”, odpowiednim fundamentem jest konsekracja przez chrzest i bierzmowanie, wspólna wszystkim członkom Ludu Bożego. Szafarze pełniący posługę święceń otrzymują oprócz tej konsekracji podstawowej także konsekrację w sakramencie święceń, aby kontynuować w czasie posługę apostolską. Osoby konsekrowane, które obierają drogę rad ewangelicznych, otrzymują nową i specjalną konsekrację, która, co prawda, nie jest sakramentalna, ale zobowiązuje je do naśladowania - przez praktykę celibatu, ubóstwa i posłuszeństwa - tej formy życia, jaką sam Jezus przyjął i dał za wzór uczniom. Choć te różne kategorie członków Kościoła objawiają jedyną tajemnicę Chrystusa, to charakterystyczną, lecz nie wyłączną cechą laikatu jest świeckość, pasterzy - służebność, zaś osób konsekrowanych - szczególne upodobnienie do Chrystusa czystego, ubogiego i posłusznego.

VC 32: W tej harmonijnej jedności darów każdy z podstawowych stanów życia ma za zadanie wyrażać - we właściwym mu zakresie - taki lub inny wymiar jedynej tajemnicy Chrystusa. Jeśli głoszenie ewangelicznego orędzia w sferze rzeczywistości doczesnych jest szczególną misją życia świeckiego, to w łonie wspólnoty kościelnej niezastąpioną rolę odgrywają ci, którzy należą do stanu duchownego, a nade wszystko Biskupi. Ci ostatni mają prowadzić Lud Boży głosząc Słowo, udzielając sakramentów i sprawując świętą władzę w służbie kościelnej komunii, która jest komunią organiczną, zorganizowaną według porządku hierarchicznego.

Natomiast w ukazywaniu świętości Kościoła obiektywne pierwszeństwo należy przyznać życiu konsekrowanemu, jako że odzwierciedla ono sposób życia Chrystusa. Właśnie dlatego najobficiej objawiają się w nim ewangeliczne dobra 
Sięgając do przeszłości, dostrzegamy, że Duch Święty zawsze wzbudzał odpowiednie charyzmaty, adekwatne do potrzeb czasu i miejsca. Każda z tych form znajdzie właściwe sobie odniesienie do Jezusa Chrystusa, do etapów Jego życia i działalności. Ogólnie ujmując, eklezjalne życie konsekrowane poznało etapy:

- w świątyni (od czasów apostolskich: dziewice, wdowy, asceci);

- na pustyni (monastycyzm anachorecki i cenobityczny; jeśli nie można przemieniać życia całej społeczności, podejmuje się odpowiedzialność za przemianę siebie. Mocowano się ze Złym, nabywano cnoty i umiejętność rozeznawania duchowego, by prowadzić innych potrzebujących formacji duchowej (np. święci: Antoni Egipski, Pachomiusz, Bazyli, Paweł z Teb, Hieronim ze Strydonu itd.);

- pośród ludzi w mieście (np. św. Augustyn w Tagaście i Hipponie - wspólnota w mieście jako przestrzeń pogańskiej, zmienia je w miejsce chwały Bożej; w średniowieczu franciszkanie z klasztorami w murach miejskich);

- na górze: (np. św. Benedykt - wyeksponowanie sursum, wejście w szkołę służby Bożej z wertykalnym postrzeganiem rzeczywistości swego życia, które ma być posłuszne Bogu);

- w wędrówce z orędziem Ewangelii (np. święci: Franciszek, Dominik, Ignacy);

Na obecnym etapie dziejów obserwujemy powrót do pierwotnych form i oswajamy się z różnorodnymi formami nowymi, które wzbudza Duch Święty wobec potrzeb naszego czasu.

\section{Konsekracja życia przez profesję rad ewangelicznych}

Człowiek powołany do służby Bogu - w sytuacji wewnątrzeklezjalnej - nie nadaje własnemu poświęceniu ,autorskiego” kształtu, lecz ,jest formowany" w ramach tej Ofiary z siebie, jaką złożył za wszystkich Syn Boży, jest dopuszczony do jedynego Opus Dei, które przywraca ludzkość Ojcu.

W kluczu paraboli można oddać istotę konsekracji życia za pomocą trzech elementów, mających też charakter etapów: powołanie, poświęcenie, uświęcenie.

i najpełniej urzeczywistnia cel Kościoła, to znaczy uświęcenie ludzkości. Życie konsekrowane zapowiada i w pewien sposób uprzedza nadejście przyszłej epoki, kiedy to nastąpi pełnia Królestwa niebieskiego, które już teraz jest obecne w zalążku i w tajemnicy, i kiedy po zmartwychwstaniu ludzie nie będą się już żenić ani wychodzić za mąż, lecz będą niczym aniołowie Boży (por. Mt 22, 30).. 
Teologia duchowości (wybraństwo i wezwanie) VOCATIO SANCTIFICATIO (przemienione życie)

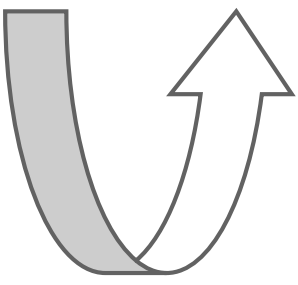

SACRIFICATIO

(ofiarowanie się i profesjonalna wierność)

Tajemnicze Boże wybranie, dociera do osoby w formie ,głosu powołania" (vocatio), który sygnalizuje Boży zamysł wobec niej. Można powiedzieć, że powołanie jest swego rodzaju „myślą opatrznościową Stwórcy [...] Jego ideą-projektem, jakby pewnym marzeniem, które jest w sercu Boga..."21. Człowiek, czując się jego adresatem, staje się zdolny do wyjścia z dotychczasowego stylu życia i poddania się prowadzeniu, które pozwoli zweryfikować, czy Bóg rzeczywiście wzywa i do jakich zadań prowadzi.

Doświadczenie wyjścia jest paradygmatem życia chrześcijańskiego, zwłaszcza tych, którzy przyjmują powołanie specjalnego poświęcenia się służbie Ewangelii. Polega ono na postawie nieustannego nawrócenia i przemiany, na byciu zawsze w drodze, na przechodzeniu ze śmierci do życia, tak jak to celebrujemy w całej liturgii: jest dynamiką paschalną22.

Należy podkreślić zdecydowanie, że konieczne jest zweryfikowanie - osobiste i przez przedstawicieli Kościoła - tego co jawi się jako powołanie, rozeznane subiektywnie. W przypadku rzeczywistego powołania, odpowiedź osoby przybiera postać decyzji ofiarowania siebie.

Oto sens powołania do życia konsekrowanego: jest ono wyłączną inicjatywą Boga (por. J 15, 16), który oczekuje od tych, których wybrał, odpowiedzi w postaci całkowitego i wyłącznego oddania się Jemu. Doświadczenie tej bezinteresownej miłości Boga jest tak głębokie i silne, że człowiek czuje się zobowiązany odpowiedzieć na nie bezwarunkowym poświęceniem Mu własnego życia, złożeniem w ofierze wszystkiego teraźniejszości i przyszłości - w Jego ręce (VC 17).

21 Papieskie Dzieło Powołań Kościelnych, Nowe powołanie dla nowej Europy: In verbo tuo..., nr 13a; Pallottinum 1998, s. 21. Jest to dokument końcowy Kongresu poświęconego powołaniom do kapłaństwa i życia konsekrowanego, jaki odbył się w Rzymie (5-10 V 1997). 
Sacrificum ze swej natury wpisuje się w kontekst liturgii, czynności starannie przez Kościół dopracowanych teologicznie i obrzędowo. Ofiarowanie się osoby powołanej dla całego Kościoła staje się świętem, stąd oprawa liturgiczna złożenia profesji ma charakter uroczysty. Zwykle wpisuje się w celebrację Eucharystii, której kwintesencję stanowi konsekracja tego, co ofiaruje Lud (chleb i wino) przez pośrednictwo kapłana (czynności zarezerwowane), by tenże Lud otrzymał przeistoczone przez Boga dary, na pożytek osobisty i wspólnotowy. Zachodzi wyraźna analogia między konsekracją eucharystyczną a konsekracją osób w tym, co ściśle określone:

- co jest ofiarowane (tam chleb i wino) - tu życie osoby (teraźniejszość i przyszłość);

- gdzie jest ofiarowane (tam w rękach kapłana, relacja osobowa) - tu w charyzmacie danego instytutu lub indywidualnej formie życia konsekrowanego;

- jak jest ofiarowane (tam własne Chrystusowe słowa - On Ofiarą i Kapłanem) - tu formuła profesji zatwierdzona przez Kościół, adekwatna do formy ofiarowania się (różne formuły przyrzeczeń, ta sama konsekracja).

To, co jest ,aktem” w celebracji (fakt o wymiarze mistycznym) konsekracji osoby, mocą prawa kanonicznego wprowadza osobę do „stanu życia” w Kościele, mającym trwałą formę. Prawo kościelne zabezpiecza - nie tylko prewencyjnymi kanonami przed niewiernością i deformacją - sakralność tego faktu, tj. danego Bogu słowa, w którym człowiek oddaje Mu siebie (res sacrum). Strzeże też jego konsekwencji, które powinny przełożyć się na kolejne godziny i lata życia, które nie należą już do człowieka (,wydane" w ręce Boga, by je spożytkował według swych zamysłów).

Docelowo wszystko zmierza do tego, by osoba konsekrowana upodobniła się całkowicie przez swą wierność do Jezusa Chrystusa, w takim stopniu, by mogła z Nim - na sposób oblubieńczy - tworzyć jedno. Adhortacja Vita consecrata podkreśla, że rady ewangeliczne „bardziej niż wyrzeczeniem” są dla powołanego „specyficzną formą przyjęcia tajemnicy Chrystusa" (VC 16).

Rady ewangeliczne - w przeciwieństwie do norm Dekalogu - „nie zajmują się bezpośrednio grzechem, ale dobrym, lepszym i najlepszym wyborem"23. Hans Urs von Balthasar podkreśla, że tym, co człowiek ofiaruje Bogu nie może być zaledwie

23 B. Cole, P. Conner, Petnia chrześcijaństwa. Teologia życia konsekrowanego, tł. A. M. Nowak, D. Dowjat, Poznań 1997, s. 26. 
Teologia duchowości rezygnacja, lecz aktywna, żarliwa miłość. Z tego tworzywa Bóg może uformować wszystko, co tylko zechce [...] bez tego tworzywa Bóg nie mógłby zrealizować wszystkiego, co zechce. Nie mógłby np. «jednać ze sobą świata»... ${ }^{24}$.

Zasada sequela Christi nie odnosi się jedynie do naśladowania cnót i postaw historycznej osoby Chrystusa; osoba konsekrowana poprzez śluby jednoczy swoje życie ze Zmartwychwstałym, obecnym w Kościele (zob. Mt 28,20). Zabiega o autentyczną ,chrystomorfozę i chrystyfikację życia"25, jego całkowitą chrystoformizację ${ }^{26}$. Kodeks Prawa Kanonicznego podkreśla, że wskutek ofiarowania się ludzkiej osoby Bogu, odtąd „całe jej istnienie staje się ustawiczną czcią Boga w miłości”(kan. 607 $\S 1$ ), a to możliwe jest jedynie w Chrystusie. Ta sytuacja przynosi zarazem szansę poczucia sensu życia, w myśl tego, co podkreślił Sobór: „Człowiek [...] nie może odnaleźć się w pełni inaczej, jak tylko przez bezinteresowny dar z siebie samego"27.

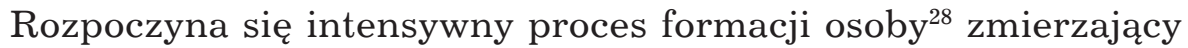
do całościowego jej przemienienia, które dokonuje się przy ludzkim zaangażowaniu, ale ostatecznie opiera się o dynamizm łaski. W tym procesie potrzeba - jak to ujął bł. papież Paweł VI - ,,bardziej niż wykształcenia intelektualnego czy wychowania woli - prawdziwego wtajemniczenia zmierzającego do chrystianizacji całej istoty człowieka, aż do głębi, w duchu ewangelicznych błogosławieństw"29. Konieczny jest duch i postawa pokory ${ }^{30}$, aby nie przeceniać zbytnio ludzkiej inwencji (np. projekty formacyjne zbytnio nasycone psychologią czy filozofią), ale dowartościować teologiczny wymiar wysiłku wychowawczego i dostrzegać Boże zaangażowanie nieodłączne od daru powołania ${ }^{31}$.

$24 \quad$ H. U. von Balthasar, Życie oddane Bogu. Sens życia wedtug rad ewangelicznych $w$ dzisiejszych czasach, „Znak” 219 (1972), tł. A. Niklewicz, s. 1165. Tekst opublikowany wcześniej w „Vie Consacrée”, 1971, nr 1.

Por. S. R. Rybicki, Paschalny charakter zakonnej konsekracji, [w:] L. Balter (red.), Apostolskie posłannictwo zakonów, Poznań 1987, s.189.

Znaczenie terminu zob. T. Paszkowska, Three notions important for consecrated life: Christ-forming - the Formation of Persons - humility, „Rocznik Teologii Katolickiej” XIV/1 2015, s. 157.

Sobór Watykański II, Gaudium et spes, nr 24.

T. Paszkowska, Three notions..., s. 161.

Paweł VI, Evangelica testificatio, nr 36.

T. Paszkowska, Three notions..., s. 168.

Tym wszystkim, którzy „nadal uważają konsekrację tylko za «poświęcenie się» człowieka, grozi ryzyko, że nigdy nie pojmą «nowości» Soboru”-uważa karmelita 
Ostatecznie poświęcenie - przyjęte i zatwierdzone przez Kościół zmierza do uświęcenia osoby powołanej ${ }^{32}$, a więc takiego doskonalenia formy tych osób, by dla nich relacja (więź) z Bogiem stała się ,samym istnieniem. Nie chodzi tylko o to, by «sprawy» Boże stawiali zawsze na pierwszym miejscu; chodzi o to, aby nie posiadali innych «spraw» niż Boże" $"$.

Adhortacja Vita consecrata eksponuje wręcz mistyczny wymiar praktykowania rad ewangelicznych, gdy stały się one poprzez profesję ,prawem życia” osoby. Praktykując je w sposób gorliwy i wierny, osoba konsekrowana „wyznaje” (confessio Trinitatis) wiarę w Trójcę Przenajświętszą i objawia tajemnice życia wewnętrznego Osób Boskich (zachowując - wyznaje) ${ }^{34}$. Stanowiące treść profesji „rady ewangeliczne bardziej niż przyczyną są skutkiem, czy raczej wymogiem konsekracji, dokonanej przez Boga wskutek wyboru danej osoby" - stwierdza kanonista E. Gambari ${ }^{35}$. Konsekracja nie jest „dziełem

Arnoldo Pigna, zob. Wprowadzenie, [w:] A. A. Ballestrero, Konsekracja, przeł. E. Dobrzelecka, Kraków 2000, s. 7.

Lumen gentium, nr 47: „Każdy zaś do ślubowania rad ewangelicznych powołany usilnie starać się winien o to, aby wytrwał i wzniósł się wyżej w tym powołaniu, do którego Bóg go wezwał, dla przysporzenia świętości Kościołowi, na większą chwałę jednej i niepodzielnej Trójcy, która w Chrystusie i przez Chrystusa jest źródłem i początkiem wszelkiej świętości”.

A. Pigna, Wprowadzenie, op. cit., s. 9.

VC 16: „Istotnie, przez profesję rad ewangelicznych osoba konsekrowana nie tylko czyni Chrystusa sensem swojego życia, ale stara się też odtworzyć w sobie - w miarę możliwości - «tę formę życia, jaką obrał sobie Syn Boży przyszedłszy na świat».

Zachowując dziewictwo, przyjmuje do swego serca dziewiczą miłość Chrystusa i wyznaje Go wobec świata jako Jednorodzonego Syna, jednego z Ojcem (por. J 10, 30; 14, 11); naśladując Jego ubóstwo, wyznaje Syna, który wszystko otrzymuje od Ojca i z miłością wszystko Mu oddaje (por. J 17, 7. 10); czyniąc ofiarę z własnej wolności, a przez to włączając się w tajemnicę Jego synowskiego posłuszeństwa, wyznaje Chrystusa jako nieskończenie umiłowanego i miłującego, jako Tego, który ma upodobanie jedynie w woli Ojca (por. J 4, 34), jest z Nim bowiem doskonale zjednoczony i we wszystkim od Niego zależy.

Dzięki takiemu «upodabniającemu» utożsamieniu się z tajemnicą Chrystusa życie konsekrowane w szczególny sposób urzeczywistnia ową «confessio Trinitatis», która jest znamienną cechą całego życia chrześcijańskiego: wyraża uznanie i podziw dla wzniosłego piękna Boga Ojca, Syna i Ducha Świętego i z radością świadczy o Jego miłościwej łaskawości wobec każdej ludzkiej istoty".

Zob. więcej T. Paszkowska, Życie konsekrowane - dynamiczny akt wiary $i$ confessio Trinitatis, „Roczniki Teologii Duchowości” 4(59) 2012, s. 75-95.

35 E. Gambari, Życie zakonne po Soborze Watykańskim II, przeł. J. E. Bielecki, Kraków 1998, s. 98. 
trzech rad ewangelicznych. To raczej odwrotnie, konsekracja skłania do ich ślubowania" 36 .

\section{Wyzwania dotyczące życia konsekrowanego}

Wypływają ze stanu faktycznego (kondycja duchowa osób i instytu-

Teologia duchowości tów), okoliczności czasu (duch światowości obecny także w Kościele, każdy wnosi go, gdy nie dość zabiega o czystość wiary i swych postaw w świecie).

Przed czterdziestu laty, niedługo po Soborze, ostrzegał o. Piotr Rostworowski, że w poruszeniach

gorączkowych reform w życiu zakonnym niemałą rolę odgrywa niestałość charakteru, nuda, jakaś acedia, znudzenie czy chandra zakonna i potrzeba zmiany. Wtedy się mówi ,aggiornamento”, trzeba czegoś nowego, to nas uratuje: zmienia się formy a dusza [pozostaje] pusta ${ }^{37}$.

Tymczasem, gdy „dla człowieka sprawy świata stają się bardzo ważne, wartości ziemskie zajmują pierwsze miejsce, to taki człowiek staje się bałwochwalcą"38.

Święta Teresa od Jezusa - której Rok Jubileuszowy 500-lecia urodzin właśnie zamknięto - w swej Twierdzy wewnętrznej (przy siódmym mieszkaniu) poucza:

[...] abyśmy nie wznosiły wysokich wież bez fundamentów, gdyż Pan patrzy nie tyle na wielkość naszych dzieł, ile na miłość, z jaką są one wykonywane. A jeżeli będziemy robiły to, co możemy, Jego Majestat sprawi, że każdego dnia będziemy mogły coraz więcej i więcej, pod warunkiem, że nie zniechęcimy się / przedwcześnie, ale przez ten krótki czas, jaki trwa to życie - a być może będzie on jeszcze krótszy niż każda z nas przypuszcza - ofiarujemy Panu wewnętrznie i zewnętrznie taką ofiarę, jaką jesteśmy w stanie Mu ofiarować, gdyż Jego Majestat połączy tę naszą ofiarę, z tą, którą On sam złożył Ojcu za nas na krzyżu, ażeby

\footnotetext{
36 Ibidem, s. 99. Por. adhortacja Redemptionis donum, nr 7: „Zobowiązanie przez śluby do spełniania rad ewangelicznych: czystości, ubóstwa i posłuszeństwa [...] stanowi z jednej strony wyraz całkowitego poświęcenia się Bogu, równocześnie zaś środek prowadzący do jego urzeczywistniania”.

$37 \quad$ Wykłady dla mistrzyń nowicjatu, Kraków 1970, mps w Archiwum Dawida Bantzlebena w Paryżu, sygn.DSB-P.R-1-5, s. 13, cyt. za: P. R. Pawlik, Mniszki? Mnisi? Ale jacy?, Kraków 2007, s. 185.

Ibidem, s. 15, cyt. za: ibidem, s. 191.
} 
- jakkolwiek te nasze dzieła same w sobie są niewielkie - miała ona przed Bogiem wartość według miary zasługi naszej woli ${ }^{39}$.

Wyzwania aktualne dotyczą przede wszystkim tego, by konsekrowani:

- nie rozumowali i nie żyli w logice, która ich życie sytuuje na jakimś innym korzeniu niż Jezus Chrystus (panmonastycyzm, dialog międzyreligijny czy filozoficzny);

- nie zanurzali się zbytnio w przeszłości, nie smakując tej nowości życia, którą daje Chrystus (homilie, konferencje w których nie dochodzi się do interpretacji Ewangelii - w wiele czasu zajmują analizy Starego Testamentu przy niedostatku odniesień do tekstów Nowego Testamentu, będących świadectwem życia Kościoła, jego formacji i dbałości o doktrynę);

- nie marnotrawili okazji jakie niesie Eucharystia do obcowania z Bogiem (skonkretyzowanym na drodze konsekracji ${ }^{40}$; konieczna jest żywa świadomość Kogo mamy przed oczyma po Przeistoczeniu, by nie obcować z abstrakcyjnymi wizjami Boga;

- by nie przedkładali ceremonii (teatralność w wymiarze horyzontalnym) nad celebracje (zawsze dające priorytet temu, co wertykalne), recytacji nad modlitwę ${ }^{41}$.

Te cztery filary wystarczą do rozpoczęcia przeformowania myślenia, postępowania, przekazywania innym Ewangelii na sposób życia przemienionego (por. VC 20).

\section{Uzasadnione nadzieje}

Nadzieja wierzącego zawsze znajduje możliwość zakotwiczenia in altum (sursum). Oddolna interpretacja tajemnicy własnego życia

39 Teresa od Jezusa, Doktor Kościoła, Zamek wewnętrzny, przeł. D. Wandzioch, W. Ciak, z oryg. Castillo interior o las Moradas, Burgos 1994; Poznań 2010, s. $452-453$.

40 Teresa od Jezusa: „Chwile po komunii świętej jest to czas, w którym dusza może zebrać zyski niezmierzone. Jeśli posłuszeństwo zaraz po komunii zawoła was do innego obowiązku, idźcie, ale starajcie się, by dusza wasza pozostała z Panem. Bo jeśli przyjąwszy Go do serca, zaraz pozwalacie myślom waszym odbiegać gdzie indziej i mało zważacie na obecność Jego w was, jakże On ma dać wam siebie poznać? To jest czas najstosowniejszy, by nas nauczał nasz Mistrz, byśmy Go słuchali..." (Droga doskonałości, rozdz. 34, 10), [w:] Św. Teresa od Jezusa, Dzieła, t. 2, przeł. H. P. Kossowski, Kraków 1987, s. 174.

41 Teresa od Jezusa uczy: „Kto modli się bez zastanowienia się nad tym, do kogo mówi, o co prosi i kto jest on, który prosi, a kto Ten, którego prosi, tego modlitwy, jakkolwiek by długo i pilnie poruszał wargami,ja nie nazwę modlitwą"-Twierdza wewnętrzna, mieszkanie I,7, [w:] Św. Teresa od Jezusa, Dzieła, t. 2, s. 228. Zob. T. Paszkowska, Nie roztrwonić życia duchowego, „Pastores” 68(2015)3, s. 47-56. 
i powołania (tożsamości), w konsekwencji także własnej misji w Kościele i świecie - zawiedzie na bezdroża. Rozeznawanie w obecnym czasie dotyczy kwestii rozpoznania tych „znaków” czy wyzwań czasu, którym można zaradzić dzięki charyzmatowi już rozeznanemu i zatwierdzonemu przez Stolicę Apostolską.

Charyzmat (instytutu czy osoby) jest tą ,płonącą lampą”, z pomocą której można rozświetlać ciemności dnia, otoczenia, nadmiaru trosk... Logika wewnątrzkościelna ma swoje zasady i punkty, które - począwszy od punktu wyjścia - wiodą jednoznacznie ku misterium wiecznego obcowania z Bogiem.

Wiara Kościoła - jak „wieczna lampka” przy Sanctissimum - powinna świecić w nas, nie wygasając, stale podtrzymując płomień oliwą wierności czerpaną z doktryny i liturgii. Naszą powinnością jest uchronić ją przed podmuchami świata i Złego, aż do dnia przyjścia Pana. Nadzieje płynące z wiary i miłości, zawsze można oprzeć:

- na Bogu, który jest wierny i działa aż do tej chwili (por. J 5, 17);

- na młodych, którzy w Kościele chcą widzieć bardziej niż słuchać, czym zmuszają do praktykowania tego, co w profesji zostało przyrzeczone (publicznie - łac. profiteri). Powinni otrzymać od formatorów zachętę, by nie widząc w starszych pokoleniach ideału, przetestowali Ewangelię na własnym życiu, choć to ciężka próba...;

- na zatroskaniu nie tyle o tzw. dzieła własne Instytutu (te moga zniknąć wkrótce), ale o dzieła Boże, które Kościół zawsze wskaże...;

- na zharmonizowaniu w sobie postaw Marii i Marty (ugościć Pana - znaczy także słuchać Go z otwartą duszą, dzień po dniu...);

Takie cztery filary nadziei, mogą dać początek innym, które się ujawnią.

Niech św. Teresa od Jezusa wypowie ostatnie słowo do nas i za nas, swym pierwszym wołaniem do Boga: „O życie, życie! Jak możesz trwać, zostając z dala od Życia twego?” (W 1,1) ${ }^{42}$.W ostatnim dodaje: „Wolę żyć i umierać w pożądaniu i oczekiwaniu żywota wiecznego, niż posiadać na tym świecie wszystkie stworzenia, wszystkie dobra i wszystko, co wraz ze światem się kończy [...] Niechaj Tobie służę na każdy dzień, a Ty czyń ze mną, co chcesz!" (W 17,6$)^{43}$.

${ }^{42}$ Wołania duszy do Boga, [w:] Św. Teresa od Jezusa, Dzieła, t. 3. Dzieła mniejsze, przeł. H. P. Kossowski, Kraków 1995, s. 153.

$43 \quad$ Ibidem, s. 183. 


\section{***}

Kluczem do odczytania misterium Kościoła i konsekracji osób przez profesję rad ewangelicznych jest w tej refleksji parabola, zastosowana do struktury konstytucji dogmatycznej o Kościele Lumen gentium i do istoty konsekracji osób.

Konsekrację ujęto „,jako doświadczenie własne”: 1) Syna Bożego (J 10, 36: hēgiasen kai apesteilen); 2) Kościoła (wszyscy konsekrowani przez chrzest i bierzmowanie; niektórzy w nowej konsekracji); 3) osoby powołanej do tego stanu.

Istotę konsekracji osób sprowadzono do trzech elementów: vocatio (zweryfikowane przez Kościół); sacrificatio (odpowiedź na powołanie $\mathrm{w}$ formie oddania życia na służbę); sanctificatio (życie przemienione, by wymownie oddziaływało - por. VC 20).

Ideał zrealizowany w Chrystusie i Kościele (różne formy dawne i nowe) stanowi wyzwanie dla współczesnych powołanych. Wyzwaniem są deformacje i kryzysy; nadzieje wiążą się z wiernością Boga, idealizmem młodych (radykalny ewangeliczny) oraz solidną formacją.

Słowa kluczowe: konsekracja, misterium, powołanie (vocatio), poświęcenie (sacrificatio - ofiarowanie się), uświęcenie (sanctificatio), formacja, chrystoformizacja.

\section{Bibliografia:}

1. Alberti G. R., Teología del misterio el pensamiento teológico de Marie-Joseph Le Guillou O.P., Mursia 2000.

2. Balthasar H. U. von, Życie oddane Bogu. Sens życia wedtug rad ewangelicznych w dzisiejszych czasach, „Znak” 219 (1972), tł. A. Niklewicz.

3. Cole B., Conner P., Petnia chrześcijaństwa. Teologia życia konsekrowanego, tł. A. M. Nowak, D. Dowjat, Poznań 1997.

4. Covolo E. dal, Studium Ojców Kościoła dla kultury zjednoczonej Europy, „Seminare" 20(2004).

5. Dąbrowski J., Nowość życia w liturgii chrztu świętego, [w:] A. J. Nowak OFM in. (red.), Chrzest - nowość życia, Lublin 1992.

6. Franciszek, List do wszystkich osób konsekrowanych na Rok Życia Konsekrowanego: Świadkowie radości, (21 XI 2014).

7. Franciszek, Wyjście jako fundamentalne doświadczenie powołania. Orędzie na Światowy Dzień Modlitw o Powołania (29 III 2015), L'OssRom(PL), $5(2015)$.

8. Gambari E., Życie zakonne po Soborze Watykańskim II, przeł. J. E. Bielecki, Kraków 1998.

9. Jan Paweł II, Adhortacja apostolska Redemptionis donum, 1984. 
Teologia duchowości

10. Jan Paweł II, Wierzę w Kościót jeden, święty, powszechny i apostolski, Libreria Editrice Vaticana 1996.

11. Kongregacja Instytutów Życia Konsekrowanego i Stowarzyszeń Życia Apostolskiego, Wskazania dotyczące formacji w instytutach zakonnych: Potissimum Institutioni (2 II 1990).

12. Liszka P., Charyzmatyczna moc życia zakonnego, Papieski Fakultet Teologiczny, Wrocław 1996.

13. Lubac H. de, Medytacje o Kościele, tł. I. Białkowska-Cichoń, Kraków 1997.

14. Moysa S., Rola Kościoła $w$ przekazywaniu Objawienia, [w:] H. Bogacki, S. Moysa (red.), Kościót w świetle Soboru, Poznań 1968

15. Ozorowski E., Bóg- Życie, Miłość, Komunia, [w:] A. Czaja, P. Jaskóła (red.), Wokót Tajemnicy Trójcy Świętej, Opole 2000.

16. Papieskie Dzieło Powołań Kościelnych, Nowe powołanie dla nowej Europy: In verbo tuo..., Pallottinum 1998.

17. Paszkowska T., Misterium konsekracji osób $w$ perspektywie duchowości Soboru Watykańskiego II, Lublin 2005.

18. Paszkowska T., Nie roztrwonić życia duchowego, „Pastores” 68(2015)3, s. 47-56.

19. Paszkowska T., Życie konsekrowane - dynamiczny akt wiary $i$ confessio Trinitatis, „Roczniki Teologii Duchowości” 4(59) 2012.

20. Pawlik P. R., Mniszki? Mnisi? Ale jacy?, Kraków 2007.

21. Pigna A., Wprowadzenie, [w:] A. A. Ballestrero, Konsekracja, przeł. E. Dobrzelecka, Kraków 2000, s. 7-11.

22. Ratzinger J., Stużyć Prawdzie, Myśli na każdy dzień, tł. ks. A. Warkotsch, Poznań - Warszawa - Lublin 1986.

23. Rybicki S. R., Paschalny charakter zakonnej konsekracji, [w:] L. Balter (red.), Apostolskie postannictwo zakonów, Poznań 1987.

24. Samsel E., „Święci” a wspólnota chrześcijan wedtug świętego Pawta Apostoła, [w:] B. Bejze (red.), W nurcie zagadnień posoborowych, t. 6: Błogosławiony Maksymilian wśród nas, Warszawa 1972.

25. Skrzypczak R., Kościót jako Niewiasta w relacji do Chrystusa swego Oblubieńca, Warszawa 2001.

26. Teresa od Jezusa, Zamek wewnętrzny, przeł. D. Wandzioch, W. Ciak, z oryg. Castillo interior o las Moradas, Burgos 1994; Flos Carmeli, Poznań 2010.

27. Teresa od Jezusa, Droga doskonatości, [w:] Św. Teresa od Jezusa, Dzieła, t. 2, przeł. H. P. Kossowski, Kraków 1987.

28. Teresa od Jezusa, Twierdza wewnętrzna, [w:] Św. Teresa od Jezusa, Dzieła, t. 2, przeł. H. P. Kossowski, Kraków 1987.

29. Teresa od Jezusa, Wołania duszy do Boga, [w:] Św. Teresa od Jezusa, Dzieła, t. 3. Dzieła mniejsze, przeł. H. P. Kossowski, Kraków 1995.

30. Wojtyła K., Znak sprzeciwu, Rekolekcje w Watykanie od 5 do 12 marca 1976, Kraków 1995. 